\title{
Nauka administracji jako subdyscyplina łącząca nauki prawne i nauki o zarządzaniu
}

\author{
The study of administration as a sub-discipline \\ combining legal and management sciences \\ Наука управления как одна из субдисциплин, \\ объединяющая в себе юридические и управленческие науки \\ STANISŁAW WRZOSEK \\ Prof. dr hab., Katolicki Uniwersytet Lubelski Jana Pawła II \\ e-mail: stanislaw.wrzosek@kul.pl, https://orcid.org/0000-0001-5557-5758
}

\begin{abstract}
Streszczenie: Analiza zagadnień związanych z organizacją i funkcjonowaniem administracji publicznej wymaga ujęcia interdyscyplinarnego. Platformą łączącą nauki prawne z naukami o zarządzaniu powinna być w tym zakresie nauka administracji traktowana jako subdyscyplina nauk prawnych. Wiąże się to z genezą nauki administracji. Następuje w niej synteza zagadnień dotyczących kierowania organizacją z zagadnieniami prawnych uwarunkowań procesu administrowania. Podstawowym przedmiotem zainteresowania nauki administracji jest aparat pomocniczy organu administracji publicznej, czyli urząd. W nauce administracji zachodzący w urzędzie proces decyzyjny jest badany z punktu widzenia realizacji przez administrację określonej przez prawo jej misji.
\end{abstract}

Słowa kluczowe: administracja publiczna, misja administracji, nauka administracji, proces decyzyjny, urząd

Summary: Analysis of issues related to the organization and function of public administration requires an interdisciplinary approach. In this respect, the study of administration should be a platform combining legal sciences with management sciences, treated as a sub-discipline of legal sciences. It is related to the genesis of the study of administration. There is a synthesis of issues related to the management of an organization with the issues of legal determinants of the administration process. The basic subject of interest in the study of administration is the auxiliary apparatus of the public authorities, i.e., the office. In the study of administration, the decision-making process taking place in the office is examined from the perspective of the implementation of the mission of administration.

Key words: Public administration, mission of administration, study of administration, decision-making process, office

Резюме: Анализ вопросов, связанных с организацией и функционированием публичной администрации, требует междисциплинарного подхода. Наука управления как субдисциплина юридических наук должна стать платформой, соединяющей юридические науки с науками об управлении. Это связано с генезисом науки управления. В ней наблюдается синтез вопросов управления организацией с вопросами, касающимися правовых условий административного процесса. Основным предметом интереса науки управления является вспомогательный аппарат публичной администрации, то есть управление. В науке управления процесс принятия решений, происходящий в управлении, рассматривается с точки зрения реализации администрацией определенной законом миссии.

Ключевые слова: публичная администрация, миссия администрации, наука управления, процесс принятия решений, управление 


\section{Wstęp}

Nauka administracji w klasycznym ujęciu uznawana jest - obok nauki prawa administracyjnego i nauki polityki administracyjnej - za element triady nauk zajmujących się organizacją i funkcjonowaniem administracji publicznej. W obecnie obowiązującej nomenklaturze podziału dziedzin i dyscyplin naukowych nie ma ona rangi odrębnej dyscypliny. Naukę administracji ze względu na jej ścisłe, tradycyjne związki w zakresie prowadzenia badań naukowych, a także działalności dydaktycznej z dyscypliną (poprzednio: dziedziną) nauk prawnych należy traktować jako nieodłączny element (subdyscyplinę) nauk prawnych. Zjawisko administrowania jest niezmiernie rozległym obszarem badawczym, w którym aspekty prawne - ustrojowe, materialne i proceduralne - są dominujące. Istnieje jednak potrzeba rozszerzania tego obszaru badawczego tak, ażeby można było zaproponować rozwiązania pozwalające na zwiększenie sprawności działania badań administracji publicznej, co jest domeną nauki administracji. W jej ramach analizuje się zagadnienia znajdujące się na granicy różnorodnych dyscyplin związanych z procesem administrowania. W dyscyplinach zaliczanych do dziedziny nauk społecznych są wykorzystywane w dużym stopniu rozważania związane z procesem kierowania, które są domeną teorii organizacji i zarządzania (obecnie w podziale dyscyplin zaliczanej do dyscypliny nauk o zarządzaniu i jakości). Znaczenie nauki administracji polega na pełnieniu przez nią funkcji łącznika pomiędzy dyscypliną nauk o zarządzaniu i jakości a dyscypliną nauk prawnych. Nauka administracji zajmuje się zagadnieniami, które nie są możliwe do pełnego przeanalizowania bez przekraczania granic pomiędzy wskazanymi dyscyplinami wiedzy. Bez wykorzystania osiągnięć nauk o zarządzaniu w zakresie systemowego ujęcia misji i celów organizacji oraz relacji organizacji z otoczeniem zewnętrznym trudno jest wypracować skuteczne metody działania przy realizacji wskazanych przez prawo zadań administracji publicznej.

Badania nad uwarunkowaniami organizacji i funkcjonowania administracji publicznej budzą zainteresowanie przedstawicieli wielu dyscyplin naukowych. Dominującą rolę w tym zakresie do niedawna odgrywały nauki zaliczane do wspomnianej wyżej tzw. triady nauk administracyjnych. Rozwój techniki, a przede wszystkim powszechna informatyzacja, oraz nowe spojrzenie na rolę pojedynczego obywatela lub grupy społecznej w procesie administrowania powodują jednak istotne rozszerzenie się kręgu dyscyplin naukowych zajmujących się zjawiskiem administrowania zarówno w ujęciu rzeczowym, jak i podmiotowym. Ponadto wykorzystanie osiągnięć nauk o zarządzaniu pozwala na analizowanie działania podsystemu społecznego administracji, a więc rozpatrywanie zagadnień związanych z poszczególnymi ludźmi lub ich zespołami zatrudnionymi w urzędach (organizacjach z punktu 
widzenia nauk o zarządzaniu) ${ }^{1}$. Warto więc spojrzeć na mającą często niedoceniane znaczenie pośród nauk prawnoadministracyjnych naukę administracji², rozumianą jako działalność naukową zajmującą się poszukiwaniem skutecznych sposobów realizacji przez państwo lub samorządy terytorialne zadań związanych z organizowaniem życia społecznego.

\section{Geneza współczesnej nauki administracji}

Nauka administracji jest związana nierozerwalnie z systemem dyscyplin naukowych, których punktem zainteresowania jest administracja publiczna w ujęciu podmiotowym i przedmiotowym. Przedstawiciele tych dyscyplin - niezależnie od stosowanych metod badawczych - koncentrują się przede wszystkim na poszukiwaniu jak najbardziej skutecznych sposobów organizowania procesu zarządzania zasobami państwa lub jego części, aby zrealizować cele postawione przez suwerena. Genezy nauk administracyjnych należy poszukiwać w poglądach kameralistów (przedstawicieli doktryny ekonomicznej w XVII i XVIII w.) i policystów ${ }^{3}$ (przedstawicieli XVIII-wiecznej nauki administracji i polityki ekonomicznej). W badaniach kameralistów wyróżniane są trzy główne okresy: pierwszy (pod wpływem merkantylizmu) koncentrował się na problematyce gospodarczej; drugi (związany z doktryną praw natury) analizował problemy interwencjonizmu państwowego; trzeci nawiązywał do dogmatycznej koncepcji prawa ustrojowego ${ }^{4}$. Wypracowanie kompleksowej oraz spójnej nauki policji miało miejsce w Niemczech w drugiej połowie XVIII w. i wiązało się z Johannem Heinrichem von Justi (Zasady nauki policji; 1756 r.) i Josephem von Sonnenfelsem (Zasady nauki policji, handlu i finansów; lata $1765-1769)^{5}$. We Francji do głównych przedstawicieli nauki o policji (policystyki)

1 Analizowanie systemu „administracja publiczna”, a w szczególności podsystemu społecznego administracji publicznej nie może ograniczać się do rozważań z zakresu nauk prawno-administracyjnych oraz oraz teorii organizacji i zarządzania. Skoncentrowanie się na tych dwóch sferach w niniejszym artykule wiąże się jedynie z ograniczeniami związanymi z charakterem publikacji.

2 Zwłaszcza należy podkreślić eksponowane $\mathrm{w}$ ramach nauki administracji ujęcie systemowe, $\mathrm{w}$ którym wyróżnia się wpływające na funkcjonowanie systemu administracji publicznej wewnątrzsystemowe i pozasystemowe uwarunkowania istniejących w administracji układów; na temat szerzej zob. Nauka administracji, red. Z. Cieślak, Warszawa 2012, s. 192 i nast.

3 Należy wspomnieć, że w XVIII w. określenie „policja” było synonimem pojęcia „administracja”. J. Malec, D. Malec, Historia administracji i myśli administracyjnej, Kraków 2003, s. 55.

4 J. Szreniawski, Wstęp do nauki administracji, Lublin 2004, s. 13.

5 J. Malec, D. Malec, Historia administracji..., s. 56 i nast. 
zaliczany był Nicolas Delamare (Traktat o policji; lata 1719-1722) . Według policystów podstawowym celem państwa było zapewnienie szczęścia (eudajmonizm) i dobrobytu poddanym. Państwo powinno realizować ten cel wszelkimi dostępnymi środkami, dążąc do tego, by stało się państwem dobrobytu. Działalność policji, czyli działalność administracyjna, nie ograniczała się do zapewnienia porządku i bezpieczeństwa publicznego, ale obejmowała również z jednej strony reglamentowanie, czyli wydawanie aktów prawnych zawierających zakazy i nakazy określonych zachowań ze strony obywateli, a z drugiej strony - rozwijanie przy użyciu form niewładczych rolnictwa, przemysłu, rzemiosła, komunikacji, oświaty, ochrony zdrowia ${ }^{7}$. Należy dodać, że zgodnie z poglądami reprezentowanymi współcześnie, funkcje administracji również ściśle wiążą się z działalnością o charakterze wykonawczym polegającą na praktycznej realizacji zadań państwowych (publicznych) ${ }^{8}$. W przypadku administracji samorządowej będą to zadania związane z zaspokajaniem potrzeb wspólnoty samorządowej, a realizowane zgodnie z zasadą subsydiarności. Elementem szeroko pojętej samodzielności jest możliwość przygotowywania rozstrzygnięć prowadzonych w ramach procesu decyzyjnego uwzględniającego cele wspólnoty lokalnej'.

Wspomniane wyżej poglądy kameralistów i policystów stanowią ilustrację występujących w XVIII i XIX w. w Europie Zachodniej koncepcji będących jednym ze źródeł nauki administracji. W literaturze panuje pogląd, iż drugim źródłem koncepcji stanowiących jedną z podstaw nauki administracji są wypracowane w XIX w. w Stanach Zjednoczonych Ameryki poglądy związane z nauką o zarządzaniu skupiające się wokół naukowej organizacji pracy w różnych jednostkach organizacyjnych ${ }^{10}$. Nie w pełni można się zgodzić z takim podziałem, gdyż np. sfera zainteresowań Henriego Fayola (1841-1925), pomimo iż działał w Europie, bliższa była zainteresowaniom teorii organizacji i zarządzania niż sferze zainteresowań europejskich administratywistów. Kierunek, który reprezentował H. Fayol, określany jest wprawdzie jako „kierunek administracyjny”, ale głównym punktem jego

6 Tamże, s. 59.

7 H. Izdebski, Historia administracji, Warszawa 1997, s. 30 i nast.

8 J. Jagielski, Zagadnienia wstępne, w: Prawo administracyjne, red. J. Jagielski, M. Wierzbowski, Warszawa 2020, s. 29.

9 Trzeba zaznaczyć, że z punktu widzenia konstrukcji polskiego samorządu terytorialnego kwestia wspólnoty samorządowej nie jest jednoznaczna. J. Zimmermann podkreśla, że „nie jest to wspólnota w semantycznie dosłownym znaczeniu, ale raczej w znaczeniu umownym. Grupa ludzi, która stanowi tę wspólnotę, nie ma bowiem wyłącznie wspólnych interesów, ale przeciwnie - w ramach każdej wspólnoty samorządowej mogą się ścierać bardzo różne interesy”. J. Zimmermann, Prawo administracyjne, Warszawa 2018, s. 272 i nast.

10 E. Knosala, L. Zacharko, A. Matan, Nauka administracji, Kraków 1999, s. 10. 
uwagi nie była administracja państwowa, tylko administracja prywatna podmiotów gospodarczych (przede wszystkim przedsiębiorstw górniczych). Podobnie wygląda kwestia poglądów niemieckiego socjologa, filozofa, prawnika i ekonomisty uznawanego za twórcę koncepcji biurokracji Maxa Webera' ${ }^{11}$ (1864-1920), którego rozważania dotyczące sprawowania władzy legalnej często uznaje się za podwaliny nauk o administracji publicznej. Koncepcja biurokratyczna M. Webera dotyczyła nie tyle zbudowania koncepcji administracji państwowej, co przede wszystkim próby przedstawienia perfekcyjnie działającej organizacji (rozumianej jako grupa ludzi działających w sformalizowanej strukturze na podstawie akceptowanych przez nich norm). W swych przemyśleniach $\mathrm{M}$. Weber posłużył się natomiast modelem administracji państwowej i dlatego jego poglądy znalazły odzwierciedlenie w nauce administracji.

W wyodrębnieniu nauki administracji z pozostałych dyscyplin zajmujących się administracją publiczną szczególną rolę odegrali niemieccy uczeni: Lorenz von Stein (1815-1890), Ignaz Jastrow (1856-1937) oraz Fritz Stier-Somlo (1873-1932). „I. Jastrow uzasadniał konieczność samodzielności nauki administracji jako odrębnej od nauki prawa administracyjnego. Jej przedmiotem winny być dwa problemy: jak się administruje oraz jak należy administrować - w tym sensie próbował on znaleźć wzorzec najlepszej administracji. Kontynuując myśl I. Jastrowa, F. Stier-Somlo używał szerszego pojęcia, a mianowicie tzw. wiedzy administracyjnej, które jest dotąd uznawane na gruncie niemieckim" ${ }^{12}$. Na skutek prac tych uczonych przyjęła się koncepcja wskazanej wyżej triady nauk administracyjnych.

Niezmiernie istotny wpływ na ukształtowanie się współczesnej nauki administracji miał - jak już to zostało zaznaczone - M. Weber. Jest on twórcą koncepcji organizacji biurokratycznej. Warto ukazać tok rozumowania, jaki przedstawił on przy opracowywaniu swojej koncepcji, gdyż widać w nim zaczątki interdyscyplinarnego podejścia do zagadnień kierowania zespołem ludzi, które jest tak ważne w naukach o administracji. W podejściu tym widać elementy o charakterze historycznym, socjologicznym, ekonomicznym i prawnym, których analiza przedstawiona jest w dziele Wirtschaft und Gesellschaft (Gospodarka i społeczeństwo; 1922 r.). Biurokracja, czyli administracja biurokratyczna, według M. Webera funkcjonuje zgodnie z dziesięcioma regułami, które dotyczą jej personelu: 1) pracownicy są osobiście wolni i podporządkowani władzy jedynie w ramach ich bezosobowych oficjalnych obowiązków; 2) pracownicy są zorganizowani w jasno określoną hierarchię stanowisk pracy; 3) każde stanowisko pracy ma jasno określoną sferę

11 Wbrew ogólnie przyjętemu mniemaniu nie jest on autorem pojęcia biurokracji, gdyż termin ten pojawił się we Francji na początku XIX w. S. Andreski, Maxa Webera olśnienia i pomyłki, tłum. K.Z. Sowa, Warszawa 1992, s. 131.

12 W. Witkowski, Historia administracji w Polsce 1764-1989, Warszawa 2007, s. 58. 
kompetencji w sensie prawnym; 4) stanowisko pracy jest obsadzane na podstawie wolnych stosunków umownych; 5) kandydaci do pracy na danym stanowisku pracy są wybierani na podstawie ich kwalifikacji fachowych; 6) pracownicy otrzymują ustalone wynagrodzenie pieniężne, a także posiadają na ogół prawo do emerytury; 7) stanowisko pracy dla osoby, która go zajmuje, jest wyłącznym, a przynajmniej podstawowym, miejscem pracy; 8) biurokratyczna organizacja stwarza warunki do kariery pracownika; 9) zatrudniony pracownik jest oddzielony od własności zasobów organizacji, a ponadto nie może zawłaszczyć swojego stanowiska; 10) w trakcie sprawowania pracy na danym stanowisku pracownik podlega ścisłej i systematycznej kontroli oraz dyscyplinie ${ }^{13}$. M. Weber uważał, że choć system biurokratyczny w swej „czystej” lub „idealnej” postaci nie istnieje, to jego wzór może być wykorzystywany w aparacie administracyjnym w celu sprawowania władzy legalnej ${ }^{14}$.

W literaturze można się spotkać z poglądem, że „ponawiane wielokrotnie, także ostatnio, w wielu krajach, próby odnowienia i wykorzystania jego [tzn. M. Webera S.W.] myśli dla usprawnienia i podniesienia skuteczności działania administracji, szczególnie ze strony socjologów badających jej funkcjonowanie, świadczą o trwałym i fundamentalnym znaczeniu dorobku Webera dla nauk administracyjnych"15. Fenomen niemieckiego badacza polegał na umiejętności spojrzenia na administrowanie $\mathrm{z}$ interdyscyplinarnego punktu widzenia, a więc takiego ujęcia, które jest jedynym możliwym do przyjęcia, gdy analizujemy system administracji publicznej. Jego spojrzenie pomimo upływu lat - zawarte w dziele Wirtschaft und Gesellschaftjest nadal aktualne. Stanowi ono wciąż istotny punkt wyjścia do analizy procesów kierowniczych w administracji publicznej.

\section{Interdyscyplinarność zagadnienia misji administracji publicznej}

W naukach o zarządzaniu analizuje się misję organizacji, odnosząc tę kwestię do zagadnienia funkcji genotypowej poszczególnych organizacji. Podkreśla się przy tym, że misja organizacji jest to kategoria socjologiczna z wyraźnym aspektem prawnym w przypadku organizacji formalnych ${ }^{16}$, do jakich z całą pewnością za-

\footnotetext{
13 J. Supernat, Management. Tezaurus kierownictwa, Wrocław 2000, s. 524 i nast.

14 J. Szreniawski, Wstęp do nauki administracji..., s. 19.

15 Tamże, s. 22.

16 L. Krzyżanowski, Podstawy nauk o organizacji i zarządzaniu, Warszawa 1992, s. 181. Według innego określenia misja jest to „deklaracja ukazująca podstawowy cel organizacji”. R.W. Griffin, Podstawy zarządzania organizacjami, tłum. M. Rusiński, Warszawa 2004, s. 214.
} 
licza się jednostki administrujące ${ }^{17}$ (urzędy). Za szczególnie przydatną w niniejszych rozważaniach można uznać definicję misji organizacji, zgodnie z którą „jest to przedmiot aspiracji, czyli trwałych dążeń organizacji (systemu), określony zwykle w akcie erekcyjnym lub w statucie jako zakres jej społecznie pożądanej działalności”18. Misja organizacji jest więc to „szczególny powód jej istnienia, wyróżniający się od wszystkich innych"19. Zdefiniowanie misji uważa się za formę określenia przez organizację swojego stosunku do otoczenia. Elementy składowe misji obejmują: a) określenie potrzeb, jakie organizacja oferuje się zaspokoić; b) ustalenie sposobu, w jaki organizacja będzie zaspokajała potrzeby otoczenia; c) „filozofię” działania organizacji w sensie szczególnych wartości, którym organizacja chce hołdować w swojej działalności ${ }^{20}$. Definicja misji organizacji na ogół opisuje wizję organizacji, a w szczególności podstawowe wartości i główny cel jej istnienia. Z reguły dotyczy przyszłości, głównie sposobu realizacji wizjii ${ }^{21}$. Swoją misję posiada - tak jak i inne organizacje - administracja publiczna zarówno jako całość, jak i jej podsystemy. Misją administracji publicznej jako organizacji (systemu) jest realizacja założeń politycznych otrzymanych od władzy zwierzchniej przez jej przedstawicieli lub bezpośrednio od społeczeństwa oraz wypełnienie założeń wypracowanych w ramach struktur administracyjnych ${ }^{22}$. W nauce administracji podkreśla się, że misja administracji publicznej, rozumianej jako system składający się z jednostek (podmiotów) administrujących, jest określana poza jej strukturą organizacyjną i należy jej poszukiwać w normach prawnych, które wskazują cele i podstawy działania tego systemu ${ }^{23}$. Na marginesie należy zaznaczyć, że misja organizacji jest zdecydowanie odróżniana od celów organizacji. Najpierw muszą być ustalone zadania organizacji, potem zdefiniowana jej misja, a wtedy dopiero sformułowane cele jej działania ${ }^{24}$. W literaturze przedmiotu został wyrażony pogląd, że w przypadku administracji publicznej przez cele można rozumieć takie wartości podstawowe, których realizacja leży w ostatecznym zamierzeniu

\footnotetext{
17 Poprzez jednostkę administrującą w tym opracowaniu rozumie się organ administracji publicznej wraz z jego aparatem pomocniczym (czyli urzędem).

18 L. Krzyżanowski, Podstawy nauk..., s. 181.

19 J.A.F. Stoner, Ch. Wankel, Kierowanie, tłum. A. Ehrilich, Warszawa 1992, s. 96.

20 J. Koziński, T. Listwan, Podstawy zarządzania organizacja, Wrocław-Poznań 2005, s. 48.

21 J. Sutherland, D. Canwell, Klucz do zarządzania strategicznego. Najważniejsze teorie, pojęcia, postaci, tłum. Z. Dziedzic, Warszawa 2007, s. 123.

22 S. Wrzosek, System: administracja publiczna. Systemowe determinanty nauki administracji, Lublin 2008, s. 49 .

23 J. Izdebski, Koncepcja misji administracji publicznej w nauce prawa administracyjnego, Lublin 2012, s. 98 .

24 J.A.F. Stoner, Ch. Wankel, Kierowanie..., s. 109.
} 
podmiotów administrujących związanym z realizacją różnorodnych wartości (np. związanych $\mathrm{z}$ interesem publicznym, interesem indywidualnym). Wartości te są celem działań administracyjnych i jednocześnie warunkiem ich realizacji ${ }^{25}$. Otoczenie administracji publicznej wymusza na niej formułowanie określonych celów, które są pochodną wartości przyjętych przez społeczeństwo, czyli stanów w jakimś względzie pożądanych przez wspólnotę albo jej część.

Zgodnie z podejściem systemowym w teorii organizacji i zarządzania administracja publiczna może być określona jako organizacja będąca system społeczno-kulturowym. Argumentami przemawiającymi za uznanie administracji publicznej za system są: 1) składa się z podsystemów (np. poszczególne resorty, urzędy, podsystem normatywny), pomiędzy którymi zachodzą wzajemne relacje; 2) można ją wyodrębnić z otoczenia zewnętrznego (przede wszystkim można wskazać, które elementy zalicza się do administracji (są składnikami jej otoczenia wewnętrznego), a które są jej otoczeniem zewnętrznym); 3) zachodzą wzajemne relacje pomiędzy podsystemami administracji a jej bezpośrednim i pośrednim otoczeniem zewnętrznym (np. poprzez przyjmowanie wniosków od obywateli i wydawanie decyzji administracyjnych); 4) administracja publiczna realizuje cele postawione jej w związku z jej misją; 5) zarówno administracja, jak i jej podsystemy są w stanie modernizować, a nawet zmieniać swoje cele (np. związane z realizacją polityki administracyjnej); 6) posiada podsystem sterujący (np. Rada Ministrów w podsystemie administracji rządowej, burmistrz w administracji samorządu miasta ${ }^{26}$.

Szukając określenia misji administracji publicznej, należy przede wszystkim odnieść się do literatury związanej z nauką prawa, a w szczególności prawa administracyjnego i prawa konstytucyjnego. Można się w tym zakresie spotkać z poglądem, że koncepcja wykorzystania pojęcia misji organizacji w analizie zjawisk zachodzących w strukturach administracji publicznej i działań w ich ramach podejmowanych wypływa wprawdzie z nauk o zarządzaniu, ale musi się odwoływać do regulacji prawnych określających zadania administracji ${ }^{27}$. Poprzez zadania administracji publicznej związane z realizacją jej misji należy rozumieć powinności państwa i jednostek samorządu terytorialnego wynikające $z$ obowiązującego prawa ${ }^{28}$. Jej zadania dzielone są na różne ich rodzaje i grupy, a jako przykład można przytoczyć określenie, że administracja jest działalnością, poprzez którą realizuje się cele bezpieczeństwa,

25 J. Boć, Uwarunkowania rozwoju administracji publicznej, w: A. Błaś, J. Boć, J. Jeżewski, Administracja publiczna, red. J. Boć, Wrocław 2003, s. 109.

26 Por. S. Wrzosek, System: administracja publiczna..., s. 17.

27 Szerzej na ten temat zob. J. Izdebski: Koncepcja misji administracji..., s. 88 i nast.

28 D. Stawasz, Zadania sektora publicznego, w: Słownikpojęć w administracji publicznej, red. I. Wieczorek, J. Szymanek, Łódź 2018, s. 224, https://www.nist.gov.pl [dostęp 30.03.2020 r.]. 
postępu i dobrobytu zbiorowości ${ }^{29}$. Za wyznaczniki funkcjonowania administracji publicznej w Polsce uznaje się w literaturze następujące zasady określone w Konstytucji Rzeczypospolitej Polskiej ${ }^{30}$ : zasadę zwierzchniej władzy narodu (art. 4); zasadę demokratycznego państwa prawnego (art. 2); zasadę praworządności (art. 7); zasada podziału i równowagi władz (art. 10); zasadę decentralizacji (art. 15); zasadę udziału samorządu terytorialnego w sprawowaniu władzy publicznej (art. 16) ${ }^{31}$. Z punktu widzenia administracji publicznej zasady te kształtują jej funkcjonowanie, chociaż rodzą też określone problemy, a w szczególności wskazuje się w literaturze na kwestię ookreślenia niektórych pojęć i wartości wpisanych do Konstytucji $\mathrm{RP}$, a także jako ciągle aktualne sygnalizuje się odwołanie do idei prawa naturalnego oraz personalistycznej koncepcji państwa prawnego ujmowanych z perspektywy kultury łacińskiej ${ }^{32}$. Niemniej wspomniane dylematy związane z zakresem zadań administracji publicznej nie wpływają na zmianę koncepcji związanych z jej misją. Realizacja tej misji, nierozerwalnie związanej z dostarczaniem przez administrację publiczną świadczeń swojemu otoczeniu, wyraża się w prowadzeniu działalności organizatorskiej. W nauce prawa administracyjnego podkreśla się, że działalność organizatorska administracji publicznej nie stoi w sprzeczności z jej wykonawczym charakterem, gdyż część swoich zadań i działań ona sama inicjuje ${ }^{33}$.

Działalność organizatorska administracji publicznej ściśle wiąże się z - mającą swe podłoże w polityce - działalnością polegającą na tworzeniu prawa. W literaturze wskazuje się jednak, że rozumienie administrowania jako prostego stosowania prawa jest już nieaktualne i sztuczne rozdzielanie polityki od administrowania staje się coraz mniej popularne $\mathrm{w}$ literaturze przedmiotu ${ }^{34}$. Aktualne jest natomiast zawsze wskazywanie roli administracji publicznej jako służebnej części aparatu państwa, dla której wydanie aktu administracyjnego nie jest celem samym w sobie, ale przede wszystkim jest instrumentem do osiągnięcia wyznaczonego przez ośrodek polityczny celu, jakim jest osiągnięcie pewnych efektów rzeczowych: budowa dróg,

29 J. Boć, Pojęcie administracji, w: Prawo administracyjne, red. J. Boć, Wrocław 2010, s. 13.

30 Konstytucja Rzeczypospolitej Polskiej z dnia 2 kwietnia 1997 r., Dz. U. z 1997 r. Nr 78, poz. 483 z późn. zm.

31 J.P. Tarno, Rola administracji publicznej w świetle przepisów nowej Konstytucji, Zeszyty Naukowe WSP w Bydgoszczy. Administracja Publiczna 2000, z. 2, s. 30, https://repozytorium.ukw.edu.pl [dostęp: 30.03.2020 r.].

32 M.Zdyb, Konstytucyjne podstawy ładu publicznego w administracji wświetle Konstytucji oraz orzecznictwa. Zagadnienia wybrane, Annales Universitatis Mariae Curie-Skłodowska, Sectio G: Ius 2017, t. 64, nr 1, s. 57.

33 J. Zimmermann, Prawo administracyjne..., s. 43.

34 B.G. Peters, Administracja publiczna w systemie politycznym, tłum. K.W. Frieske, Warszawa 1999, s. 18 . 
utrzymanie szkół, ochrona zdrowia itp. ${ }^{35}$. Jeżeli przyjmie się określenie polityki jako zespołu „działań podjętych przez ośrodek decyzyjny, zmierzających do osiągnięcia zamierzonych celów za pomocą odpowiednio dobranych środków"36, to będzie można oddać specyfikę funkcjonowania administracji publicznej z punktu widzenia nauki administracji. Do administracji publicznej należy bowiem nie tylko ciągłe dokonywanie wyborów (czyli podejmowania decyzji w rozumieniu nauk o zarządzaniu), ale również wpływanie na otoczenie zewnętrzne, aby te rozstrzygnięcia były akceptowane przez ich adresatów. Działalność administracji publicznej nie jest bowiem skierowana na bezpośrednie zaspokajanie własnych potrzeb. Skierowana do otoczenia zewnętrznego decyzja będąca aktem woli organu administrującego może zezwalać, nakazywać lub tolerować określone zachowania podmiotów znajdujących się w jej otoczeniu zewnętrznym. Decyzja taka będąca wynikiem określonego procesu rozstrzyga bardzo często o wyborze realizacji określonych interesów, często stojących w sprzeczności z innymi interesami występującymi w życiu społecznym czy gospodarczym ${ }^{37}$. Na decyzje podejmowane w ramach procesów administrowania mają wpływ zmiany zachodzące $\mathrm{w}$ otoczeniu jednostki administrującej. Zmiany zachodzące w otoczeniu wewnętrznym i zewnętrznym organizacji charakteryzują się sprzężeniem zwrotnym, a więc są wzajemnie uwarunkowane. $\mathrm{W}$ praktyce zarządzania (kierowania), także $\mathrm{w}$ ramach organizacji posiadających administracyjną funkcję genotypową, a więc i przy podejmowaniu rozstrzygnięć w ramach wykonywania administracji publicznej, wskazane sprzężenia muszą być uwzględniane. Wiąże się to z potrzebą stałego obserwowania zachodzących zmian i analizowania ich wpływu na cele organizacji ${ }^{38}$. Przykładem wpływu otoczenia zewnętrznego na administrację publiczną jest jej przekształcanie się związane z potrzebami społeczeństwa informacyjnego. „Administracja wychodząc naprzeciw oczekiwaniom dobrze poinformowanego społeczeństwa musi zrewidować obowiązujące dotąd pryncypia związane choćby z zasadą pisemności rozstrzygania spraw czy szerzej formalnego komunikowania się z obywatelami (odejście od cywilizacji papieru na rzecz cywilizacji komputerowej)"39. Za taki wpływ można obecnie

35 Na ten temat zob. np. J. Filipek, Prawo administracyjne. Instytucje ogólne, cz. 1, Kraków 1995, s. 17. Autor ten swoje rozważania na temat określenia administracji państwowej rozpoczął od nawiązania do kryteriów interesów prywatnych i publicznych na gruncie prawa rzymskiego.

36 M. Chmaj, Przyczynek do wyjaśnienia pojęcia: polityka, Annales Universitatis Mariae Curie-Skłodowska, Sectio K: Politologia 1995-1996, t. 2, nr 3, s. 205.

37 E. Knosala, Zarys teorii decyzji w nauce administracji, Warszawa 2011, s. 23.

38 B. Wawrzyniak, Decyzje kierownicze w teorii i praktyce zarzadzania, Warszawa 1980, s. 36.

39 Z. Niewiadomski, Nowe zjawiska $w$ administracji publicznej - perspektywa teorii prawa administracyjnego, w: Nowe zjawiska w administracji publicznej, red. Z. Cieślak, A. Kosieradzka-Federczyk, Warszawa 2015, s. 46. 
uznać także sytuację społeczną i gospodarczą związaną z pandemią wirusa COVID-19. Wpływ otoczenia zewnętrznego na administrację publiczną jest często analizowany w publikacjach związanych z nauką administracji. Przykładem tego są rozważania, w których sprawność działania struktur administracyjnych powiązano bezpośrednio $\mathrm{z}$ ich otoczeniem wewnętrznym (sposobem zorganizowania tych struktur) i otoczeniem zewnętrznym (stopniem złożoności tego otoczenia i dynamiki zachodzących w nim przemian $)^{40}$. Otoczenie zewnętrzne wpływa więc $\mathrm{w}$ istotnym stopniu na określanie oraz korygowanie celów administracji publicznej. Cele operacyjne, taktyczne, a nawet strategiczne administracji związane z oczekiwaniami społecznymi mogą ulegać zmianom. Otoczenie zewnętrzne nie powinno jednak zmienić misji administracji, którą jest podejmowanie działań na rzecz dobra obywateli.

Określenie celu organizacji pozwala odpowiedzieć na pytanie o sens jej istnienia. Z punktu widzenia nauki administracji istotne jest, że pojęciem celu posługują się organy administracji publicznej wydające akty normatywne ${ }^{41}$. Akt ten jako prawna forma działania administracji publicznej znajduje się w orbicie zainteresowań nauki prawa administracyjnego, a sposób jego przygotowania jest obiektem badań związanych z naukami o zarządzaniu, a w rezultacie nauki administracji.

Prowadzona w ramach nauki administracji analiza celu organizacji (jednostki administrującej) pozwala zakwalifikować ją do jednej z trzech kategorii: organizacji, które istnieją w celu zapewnienia korzyści swoim akcjonariuszom; organizacji, które nie uznają pomnażania bogactwa akcjonariuszy za wyłączny cel swego istnienia, a w swoim funkcjonowaniu kierują się także oczekiwaniami swoich pozostałych interesariuszy; organizacji, których nie zadowala jedynie zaspokajanie potrzeb interesariuszy, gdyż poszukują one wyższego celu niż zaspokajanie potrzeb interesariu$\mathrm{szy}^{42}$. Do tej ostatniej - trzeciej - kategorii należy zaliczyć administrację publiczną, o ile w jej działaniu nie występują zjawiska o charakterze patologicznym. Opracowanie strategii umożliwia osiągnięcie celu funkcjonowania organizacji, a przede wszystkim pozwala organizacji na wypracowanie logiki jej funkcjonowania ${ }^{43}$. Odnośnie do standardów zachowania należy w pełni zgodzić się z poglądem, że „organizacja musi przyjąć politykę i zasady zachowania, które pomogą pracownikom

\footnotetext{
40 J. Łukasiewicz, Zasada organizacyjnej elastyczności aparatu administracji publicznej, Warszawa 2006, s. 44 .

41 A. Mituś, Cel wadministracji publicznej i prawie administracyjnym. Studium teoretycznoprawne, Warszawa 2018, s. 12.

42 J. Supernat: Zarzadzanie, Wrocław 2005, s. 371.

43 Tamże, s. 371.
} 
podejmować codzienne decyzje"44. Przedstawiona koncepcja odnosi się zasadniczo do organizacji określanych jako organizacje gospodarcze czy ekonomiczne, które mają przede wszystkim na celu osiągnięcie własnego dobrobytu, ale można ją odnieść z całą pewnością także do organizacji tworzonych z myślą o zapewnieniu powodzenia ich otoczenia zewnętrznego. Do kręgu takich organizacji należy właśnie zaliczyć administrację publiczną i jej podsystemy. Od organizacji o charakterze ekonomicznym w omawianym zakresie odróżnia administrację publiczną fakt, że jej misja i związane z nią cele działania - ze względu na funkcję wykonawczą - są jej nadane przez otocznie zewnętrzne. Można w tym zakresie mówić zarówno o otoczeniu zewnętrznym bezpośrednim, np. o organach władzy lub organach wymiaru sprawiedliwości, jak i o otoczeniu zewnętrznym ogólnym, np. o systemie prawnym.

\section{Zagadnienie misji organizacji w ujęciu nauki administracji}

W rozważaniach prowadzonych na gruncie nauki administracji będącej zarówno pod wpływem nauki prawa administracyjnego, jak i nauk o zarządzaniu można oprzeć się na oddającym w pełni istotę misji organizacji określeniu, że „jest to fundamentalny a równocześnie unikatowy stan przyszły do którego organizacja zamierza. Misja jest ogólnym stwierdzeniem najbardziej podstawowych intencji [organizacji - S.W.]”45. Przykładem sformułowania misji organizacji jest: „Jesteśmy firmą najwyższej uczciwości, oddaną naszym pracownikom i klientom, a naszą misją jest osiągnięcie pozycji krajowego lidera pod względem sprzedaży i rentowności sprzedaży wysokiej jakości systemów bezpieczeństwa dla amerykańskich gospodarstw domowych i rodzin”46. Dla porównania można przytoczyć określenie misji urzędu (aparatu pomocniczego organu administracji), zaliczanego do organizacji posiadających administracyjną funkcję genotypową, a więc - jak to było już wyżej zaznaczone - organizacji, która jest powołana do działania nie na rzecz realizacji własnych interesów, ale realizacji interesów otoczenia zewnętrznego (przede wszystkim bezpośredniego). Jako przykład może służyć misja określona w ramach administracji samorządowej, a mianowicie misja Urzędu Miasta Siedlce: „Misją

\footnotetext{
44 Tamże, s. 371.

45 K. Obłój, M. Trybuchowski, Zarządzanie strategiczne, w: Zarządzanie. Teoria i praktyka, red. A.K. Koźmiński, W. Piotrowski, Warszawa 1995, s. 202, https://edu.pjwstk.edu.pl/wyklady/poz/scb/ index21.html [dostęp: 11.08.2017 r.].

46 B. Tracy, Turbostrategia. 21 skutecznych sposobów na przekształcenie firmy i szybkie zwiększenie zysków, tłum. G. Łuczkiewicz, Rzym 2010, s. 49.
} 
Urzędu Miasta jest działać sprawnie, przyjaźnie i bezpiecznie. Realizujemy zasadę samorządności u której podstaw leży profesjonalne świadczenie usług zaspokajających zbiorowe i indywidualne potrzeby mieszkańców i gości w celu zwiększenia ich zadowolenia i umocnienia roli Urzędu jako instytucji służby publicznej [...]"47. Jako przykład sformułowania misji w ramach struktur administracji publicznej można również podać określenie związane $\mathrm{z}$ funkcjonowaniem administracji rządowej i tak misją Krajowej Administracji Skarbowej jest „zapewnienie stabilnych i efektywnych finansów publicznych oraz wysokiej jakości świadczonych usług"48. Prawidłowe określenie misji zarówno całej administracji publicznej, jak i któregoś z jej podsystemów umożliwi administracji ukształtowanie relacji uwzględniającej interesy podmiotów administrowanych wchodzących w skład otoczenia zewnętrznego administracji. Interesy te odzwierciedlają oczekiwania podmiotu zewnętrznego, że będzie wobec niego zastosowana określona prawem forma działania administracji. Wyrażenie oczekiwań i ewentualne spowodowanie zastosowania wobec podmiotu zewnętrznego prawa materialnego zostało odzwierciedlone w triadzie Bernatzika, w której są wymienione: interes faktyczny, interes prawny i roszczenie prawne (publiczne prawo podmiotowe) ${ }^{49}$. Można stwierdzić, że realizacja wskazanych w triadzie Bernatzika interesów jest określonym w misji celem działania administracji. Nie może on być jednak rozpatrywany w oderwaniu od innych zjawisk związanych $\mathrm{z}$ administrowaniem. Dobrze to zagadnienie odzwierciedla zaprezentowana $\mathrm{w}$ literaturze triada zjawisk związanych $\mathrm{z}$ pojęciem administracji publicznej, a mianowicie: cel - struktura konieczna do jego realizacji - zadania struktu$\mathrm{ry}^{50}$. Z całą pewnością kwestie struktury pozostają w sferze zainteresowań nauki administracji, która odgrywa tutaj rolę subdyscypliny łączącej nauki o zarządzaniu i nauki prawne.

Nad misją administracji publicznej można zastanawiać się z punktu widzenia całego „aparatu” administracji publicznej w skali państwa, traktując ją jako niezmiernie rozbudowaną i skomplikowaną w swoim funkcjonowaniu organizację (w ujęciu teorii organizacji i zarządzania), czyli system, a właściwie megasystem (w ujęciu ogólnej teorii systemów). Można też rozpatrywać misję w wybranym podsystemie administracji publicznej. W przypadku administracji terenowej,

47 Urząd Miasta Siedlce, https://umsiedlce.home.pl/ [dostęp: 23.02.2021 r.].

48 Ministerstwo Finansów - Krajowa Administracja Skarbowa, Strategia KAS, https://www.gov.pl/web/ kas/strategia-kas [dostęp: 23.02.2021 r.].

49 J.Zimmermann, Prawo administracyjne ..., s. 364 i nast. We wskazanej publikacji została w wyczerpujący i interesujący sposób przedstawiona ta konstrukcja teoretyczna (tamże, s. 364 i nast.).

50 Z. Niewiadomski, Pojęcie administracji publicznej, w: System Prawa Administracyjnego, t. 1. Instytucje prawa administracyjnego, red. R. Hauser, Z. Niewiadomski, A. Wróbel, Warszawa 2010, s. 47. 
zarówno samorządowej, jak i rządowej, analiza misji nie może być oderwana od regionalnych czy lokalnych uwarunkowań społecznych, ekonomicznych, a nawet geograficzno-przyrodniczych.

Prawidłowe sformułowanie misji administracji jest zagadnieniem, które zdecydowanie wykracza poza pole zainteresowań nauki prawa administracyjnego, a nawet spokrewnionych $z$ nią nauki administracji i nauki polityki administracyjnej. Konieczne jest w tym zakresie ujęcie interdyscyplinarne wiążące się z wzajemnym uwzględnianiem osiągnięć różnorodnych dyscyplin naukowych, przede wszystkim z obszaru nauk społecznych.

\section{Zakończenie}

Administracja publiczna jest obiektem zainteresowania nie tylko nauk prawnych, ale także innych dyscyplin zaliczanych do dziedziny nauk społecznych. Ze względu na organizatorski charakter działalności administracyjnej wiążący się z zaspokajaniem interesów o charakterze publicznym szczególną rolę w tym zakresie odgrywa dyscyplina nauk o zarządzaniu i jakości. Niestety, często odczuwany jest brak zharmonizowania badań prowadzonych w ramach dyscyplin zajmujących się „zjawiskiem administracji”. Ciągle nie ma wspólnej platformy podchodzenia do analizowanych zjawisk. Nauka administracji i prowadzone w jej ramach badania nad organizacją oraz funkcjonowaniem administracji publicznej powinny być traktowane jako subdyscyplina nauk prawnych, która wykorzystując osiągnięcia w zakresie kierowania zespołami ludzkimi wypracowane na gruncie nauk o zarządzaniu, będzie mogła wskazać sposoby realizacji celów określonych przez prawo, a w szczególności przez normy prawa administracyjnego. Rozważania związane z misją organizacji, a przede wszystkim organizacji posiadających administracyjną funkcję genotypową, mogą być bardzo przydatne przy rozwiązywaniu problemów dotyczących kształtowania procesu decyzyjnego w ramach struktur administracyjnych. Istotne w tym zakresie mogą okazać się kwestie związane z określeniem misji i celów działania administracji publicznej. Odchodzenie od czysto reglamentacyjnych funkcji administracji w stronę realizacji w coraz większym stopniu zadań z zakresu administracji świadczącej wymaga zmian w sferze organizacji urzędów, czyli aparatu pomocniczego organów administracji publicznej. Nie może się więc utrzymywać sytuacja, w której brak jest współdziałania pomiędzy przedstawicielami dyscypliny nauk prawnych i dyscypliny nauk o zarządzaniu. Platformą porozumienia i współdziałania w tym zakresie powinna być 
nauka administracji rozumiana jako subdyscyplina, której przedmiotem jest analiza organizacyjnych aspektów realizacji założeń prawa w ramach struktur administracyjnych.

\section{Bibliografia}

Andreski S., Maxa Webera olśnienia i pomyłki, tłum. K.Z. Sowa, Warszawa 1992.

Błaś A., Boć J., Jeżewski J., Administracja publiczna, red. J. Boć, Wrocław 2003.

Boć J., Pojęcie administracji, w: Prawo administracyjne, red. J. Boć, Wrocław 2010.

Chmaj M., Przyczynek do wyjaśnienia pojęcia: polityka, Annales Universitatis Mariae Curie-Skłodowska, Sectio K: Politologia 1995-1996, t. 2, nr 3.

Filipek J., Prawo administracyjne. Instytucje ogólne, cz. 1, Kraków 1995.

Griffin R.W., Podstawy zarządzania organizacjami, tłum. M. Rusiński, Warszawa 2004.

Izdebski H., Historia administracji, Warszawa 1997.

Izdebski J., Koncepcja misji administracji publicznej w nauce prawa administracyjnego, Lublin 2012.

Jagielski J., Zagadnienia wstępne, w: Prawo administracyjne, red. J. Jagielski, M. Wierzbowski, Warszawa 2020.

Knosala E., Zacharko L., Matan A., Nauka administracji, Kraków 1999.

Knosala E., Zarys teorii decyzji w nauce administracji, Warszawa 2011.

Koziński J., Listwan T., Podstawy zarządzania organizacją, Wrocław-Poznań 2005.

Krzyżanowski L., Podstawy nauk o organizacji i zarządzaniu, Warszawa 1992.

Łukasiewicz J., Zasada organizacyjnej elastyczności aparatu administracji publicznej, Warszawa 2006.

Malec J., Malec D., Historia administracji i myśli administracyjnej, Kraków 2003.

Mituś A., Cel w administracji publicznej i prawie administracyjnym. Studium teoretycznoprawne, Warszawa 2018.

Nauka administracji, red. Z. Cieślak, Warszawa 2012.

Niewiadomski Z., Nowe zjawiska $w$ administracji publicznej-perspektywa teorii prawa administracyjnego, w: Nowe zjawiska w administracji publicznej, red. Z. Cieślak, A. Kosieradzka-Federczyk, Warszawa 2015.

Niewiadomski Z., Pojęcie administracji publicznej, w: System Prawa Administracyjnego, t. 1. Instytucje prawa administracyjnego, red. R. Hauser, Z. Niewiadomski, A. Wróbel, Warszawa 2010.

Obłój K., Trybuchowski M., Zarządzanie strategiczne, w: Zarządzanie. Teoria i praktyka, red. A.K. Koźmiński, W. Piotrowski, Warszawa 1995, https://edu.pjwstk.edu.pl/wyklady/ poz/scb/index21.html [dostęp: 11.08.2017 r.].

Peters B.G., Administracja publiczna w systemie politycznym, tłum. K.W. Frieske, Warszawa 1999.

Stawasz D., Zadania sektora publicznego, w: Słownikpojęć w administracji publicznej, red. I. Wieczorek, J. Szymanek, Łódź 2018, https://www.nist.gov.pl [dostęp: 30.03.2020 r.]. 
Stoner J.A.F., Wankel Ch., Kierowanie, tłum. A. Ehrlich, Warszawa 1992.

Supernat J., Management. Tezaurus kierownictwa, Wrocław 2000.

Supernat J., Zarządzanie, Wrocław 2005.

Sutherland J., Canwell D., Klucz do zarządzania strategicznego. Najważniejsze teorie, pojęcia, postaci, tłum. Z. Dziedzic, Warszawa 2007.

Szreniawski J., Wstęp do nauki administracji, Lublin 2004.

Tarno J.P., Rola administracji publicznej w świetle przepisów nowej Konstytucji, Zeszyty Naukowe WSP w Bydgoszczy. Administracja Publiczna 2000, z. 2, https://repozytorium.ukw.edu.pl [dostęp: 30.03.2020 r.].

Tracy B., Turbostrategia. 21 skutecznych sposobów na przekształcenie firmy i szybkie zwiększenie zysków, tłum. G. Łuczkiewicz, Rzym 2010.

Wawrzyniak B., Decyzje kierownicze w teorii i praktyce zarzadzania, Warszawa 1980.

Witkowski W., Historia administracji w Polsce 1764-1989, Warszawa 2007.

Wrzosek S., System: administracja publiczna. Systemowe determinanty nauki administracji, Lublin 2008.

Zdyb M., Konstytucyjne podstawy ładu publicznego w administracji w świetle Konstytucji oraz orzecznictwa. Zagadnienia wybrane, Annales Universitatis Mariae Curie-Skłodowska, Sectio G: Ius 2017, t. 64, nr 1.

Zimmermann J., Prawo administracyjne, Warszawa 2018. 